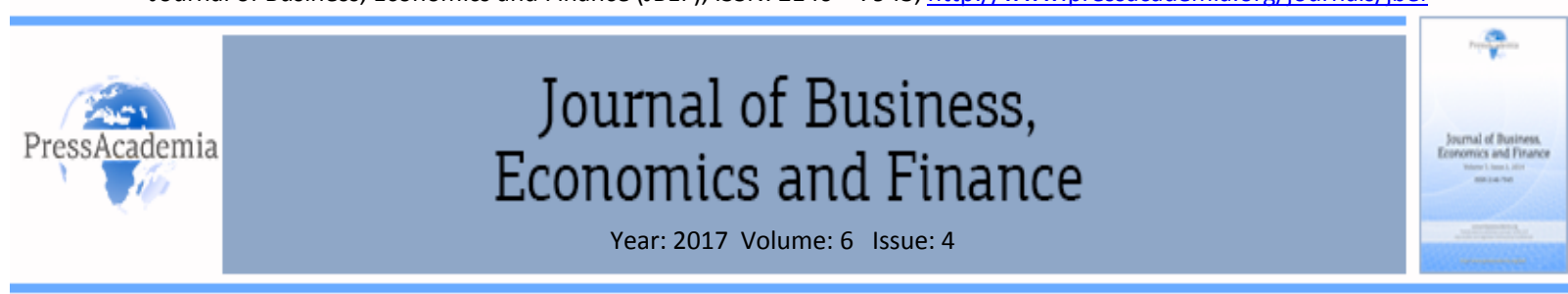

\title{
ECONOMIC IMPACTS OF CLIMATE CHANGE ON AGRICULTURE: EMPIRICAL EVIDENCE FROM ARDL APPROACH FOR TURKEY
}

\author{
DOI: $10.17261 /$ Pressacademia.2017.766 \\ JBEF- V.6-ISS.4-2017(5)-p.336-347
}

Yasemin Dumrul $^{1}$, Zerrin Kilicarslan ${ }^{2}$

Erciyes University, Develi Hüseyin Şahin Vocational School, Kayseri, Turkey. ydumrul@erciyes.edu.tr

Erciyes University, , Kayseri Vocational School, Kayseri, Turkey. zkaan@erciyes@edu.tr

To cite this document

Dumrul, Y., Kilicarslan, Z., (2017). Economic impacts of climate change on agriculture: empirical evidence from ARDL approach for Turkey. Journal of Business, Economics and Finance (JBEF), V.6, Iss.4, p.336-347.

Permemant link to this document: http://doi.org/10.17261/Pressacademia.2017.766

Copyright: Published by PressAcademia and limited licenced re-use rights only.

\begin{abstract}
Purpose- The agricultural sector is one of the sectors most sensitive to climate change. This sector is directly affected by temperature and precipitation, which is an input in agricultural production. The main objective of this study is to evaluate the effects of climate change in agricultural production in Turkey.

Methodology- The data cover the period 1961-2013. In this study, economic effects of climate change on agriculture were analyzed for Turkey using a time series approach.

Findings- The increase in precipitation affects agricultural GDP positively, while the increase in temperature has a negative effect on agricultural GDP.

Conclusion- In order to minimize the adverse effects of climate change in Turkey, which is one of the largest countries in the world in terms of agricultural land, it is important to establish policies, strategies, plans and programs to combat climate change.
\end{abstract}

Keywords: Climate change, agriculture, economic impact, ARDL, Turkey

JEL Codes: Q54,, Q51, C22

\section{INTRODUCTION}

One of the most defining aspects of this century is climate change. Climate change can lead to the emergence of various socio-economic problems such as poverty, economic growth and unsustainability of development, health and safety (Swart et al., 2003). Climate change will have direct impacts on the size of state budgets (flood, conservation of forest areas, control of pollution), terms of trade (change in agricultural yield and labor productivity), economic growth rates (change in agricultural yield and labor productivity, depletion of natural resources) and social welfare (price increases, flood, pollution and health effects) (Cuervo and Gandhi, 1998). United Nations Framework Convention on Climate Change (UNFCCC) defines climate change as "a change of climate which is attributed directly or indirectly to human activity that alters the composition of the global atmosphere and which is in addition to natural climate variability observed over comparable time periods (UN, 1992). Intergovernmental Panel on Climate IPCC (2007) defines climate change as "a change in the state of the climate that can be identified by changes in the mean and/or variability of its properties that persists for an extended period, typically decades or longer". Thus, climate change refers to any change in climate over time, whether due to natural variability or as a result of human activity. The effects of climate change arise as a result of the increase in $\mathrm{CO}_{2}$ and the rise in temperature due to this increase and precipitation regime changes. While these effects are harmful to one region, they can be positive in another region. For example, increases in temperature can have both positive and negative effects on product yield (Adams et. al., 1998). Meadow and grassy areas may increase in cold regions due to warming and temperature increase can contribute to the development of livestock in these regions (Demir and Cevger, 2007). However, in general, it is suggested that the increase in temperature reduces the yield and quality of many crops. Increases in precipitation (i.e. level, timing and variability) can also benefit soil semi-arid areas and other water resources by increasing soil moisture. But while increases in precipitation may worsen problems in regions with excessive amounts of water, a 
reduction in the amount of precipitation may have an adverse effect (Adams et. al, 1998). In other words, extremes in climate elements lead to serious economic losses by increasing the frequency and severity of climate-induced natural disasters such as drought, floods and storms (Başoğlu and Telatar, 2013).

Since temperature and precipitation are a direct input into agricultural production, it is thought that the greatest impact will be on the agricultural sector (Deschenes and Greenstone, 2007; Barnwall and Kotani, 2013). Because the agricultural sector among all sectors is the most sensitive and most vulnerable to climate change (Deressa et al., 2005). The agricultural sector is a sector that creates employment, provides food security, supplies raw materials to the industry sector and provides foreign exchange input to the country in foreign trade. Surveys show that the agriculture sector has a slow growth rate over the years due to climate change. It can be said that this situation is more worrisome when the urbanization phenomenon and population growth rate are considered (Amponsah et al., 2015). Agricultural products and livestock are directly affected by changes in the climate factor, such as temperature, precipitation, the severity and frequency of extraordinary events, the increase $\mathrm{CO}_{2}$ concentration in the atmosphere, climate variability and the increase in sea level (Adams et. al., 1998). Depending on the physical characteristics of the region and the crops produced, both the positive and negative effects of climate change on agriculture can emerge (Mishra and Sahu, 2014). The changes in agricultural production are due to changes in crop yield and changes in crops (size of land, area of land). Changes in yields of crops are a result of climate change and the intervention of producers in such a way as to increase agricultural productivity. "These mitigating interventions of producers can be in the form of increasing fertilizer or water use or adopting a new crop species (Adams et. al., 1998). The rapid increase in world population will increase demand for food and fuel. For this reason, an increase in agricultural production will be needed. However, climate change puts pressure on agriculture, threatening future food production and supply, makes adaptation measures and resilience very expensive (Maharjan and Joshi, 2012).

In addition, climate change will change the prices of agricultural commodities, the reallocation of resources in the agricultural sector, the structure of many country economies and international trade patterns (Gbetibouo and Hassan, 2005). However, it also changes the comparative advantage of the country. In addition, changes in the amount of agricultural production may also have adverse effects on inflation, unemployment, current account deficit and budget. The decrease in agricultural production will have a negative effect on inflation by increasing agricultural product prices. The decrease in the number of employees in the agricultural sector will have a negative effect on unemployment. The supply deficit in agricultural products covered by imports has a negative effect on the current account deficit. Compensating for some or all of the producer damages due to climate change by governments will affect the budget negatively (Bayraç and Doğan, 2016). However, climate change has more harmful effects on agriculture. Besides, in different regions, the grade of the specified effect is different (Maharjan and Joshi, 2012). The main objective of this study is to evaluate the effects of climate change in agricultural production in Turkey. The rest of the paper is organized as follows. Section Literature Review presents the "empirical background" Section "data and methodology" describes data sources and presents our empirical strategy. Section "findings and discussions" describes the emprical results. Section "conclusion" concludes.

\section{LITERATURE REVIEW}

Different approaches have been adopted in different studies on economic effects of climate change in agriculture. These are mentioned below.

i. The approach of functioning (also known as crop modeling or agronomic-economic approach)

ii. Ricardian Approach

iii. Advanced Ricardian (Panel Data) Approach

iv. The time series approach

Two of the most commonly used approaches to these approaches are "Production function approach"(known as product modeling and agricultural models) and "Ricardian Approach" (Guiteras, 2005; Sarker et al.,2014; Barnwall and Kotani, 2013).

\subsection{Production Function Approach}

The production function approach is based on empirical or empirical analysis of the relationship between climate variables (environmental factors) and yield (Deressa et al. 2005).This approach, which is used to predict the impact of climate change, is based on empirical or experimental production functions to estimate environmental damage. This approach, also known as product modeling, deals with a basic production function and estimates the effects of climate change by changing one or more input variables such as temperature, precipitation and carbon dioxide levels (Mendelsohn et.al., 1994). This approach based on controlled experiments simulates (several transient climate change scenarios) climate factors and product yields in a laboratory-type environment. This approach does not take into account farmers' attitudes towards adaptation, although climate change is a useful basis for predicting the impact on farming (Mishra and Sahu, 2014). In other 
words, in response to climate change, farmer adaptations such as farmers changing fertilizers, differentiating the composition of crops, or using agricultural land for another activity (such as a housing complex) are totally ignored in the approach of production function (Deschenes and Greenstone, 2007). This leads to an overestimate of the negative effects and an underestimation of the positive effects (Sarker et al., 2014; Mendelsohn et.al., 1994). In other words, there is a tendency to predict too much prejudice and damage in studies based on this approach. This prejudice is sometimes called to as a "dumb farmer scenario" to express that farmers neglect the various adaptations that they give in response to changing economic and environmental conditions (Mendelsohn et.al., 1994). Table 1 presents the literature summary of the production function approach.

Table 1: Studies on The Impact of Climate Change on Agriculture: Production Function Approach

\begin{tabular}{|c|c|c|c|}
\hline Author & Period/Country & Variables & Results \\
\hline $\begin{array}{l}\text { Aggarwal et. al. } \\
\text { (2010) }\end{array}$ & $\begin{array}{l}11 \text { districts of the } \\
\text { Upper Ganga } \\
\text { Basin, India } \\
1969-1990\end{array}$ & $\begin{array}{l}\text { Dependent Variable: Growth } \\
\text { and yield of rice and wheat crops } \\
\text { Independent Variable: Solar } \\
\text { radiation, temperatures, rainfall, } \\
\text { wind speed and vapour } \\
\text { pressure. }\end{array}$ & $\begin{array}{l}\text { In the simulation analysis using infoCropWheat and } \\
\text { InfoCrop-Rice models found that rice and wheat crops } \\
\text { will be affected by climate change. }\end{array}$ \\
\hline $\begin{array}{l}\text { Mathauda et al. } \\
(2000)\end{array}$ & $\begin{array}{l}\text { Punjab, India } \\
1970-1990\end{array}$ & $\begin{array}{l}\text { Dependent Variable: Rice yield } \\
\text { Independent Variable: } \\
\text { Temperature change (extreme } \\
\text { warm, greater warm, moderate } \\
\text { warm, slight warm and normal } \\
\text { weather) }\end{array}$ & $\begin{array}{l}\text { In the study, the effect of temperature on rice yield was } \\
\text { analyzed on } 5 \text { different weather scenarios. CERES RICE } \\
\text { simulation model was used in the study. The results of } \\
\text { the research show that the increase in temperature } \\
\text { reduces the rice yield in five scenarios. As the } \\
\text { temperature increases, the decrease in rice yield also } \\
\text { increases. }\end{array}$ \\
\hline $\begin{array}{l}\text { Southworth et } \\
\text { al. (2000) }\end{array}$ & $\begin{array}{l}\text { Midwestern Great } \\
\text { Lakes Region } \\
\text { 1987-1990 }\end{array}$ & $\begin{array}{l}\text { Dependent Variable: Maize } \\
\text { yields } \\
\text { Independent Variable: } \\
\text { Temperatures, rainfall }\end{array}$ & $\begin{array}{l}\text { CERES maize model was created for the period 2050- } \\
\text { 2059. It was found that high temperatures during the } \\
\text { tasseling of maize lead to significant decreases in } \\
\text { productivity. }\end{array}$ \\
\hline $\begin{array}{l}\text { Olesen et al. } \\
(2000)\end{array}$ & $\begin{array}{l}\text { Denmark } \\
\text { 1971-1997 }\end{array}$ & $\begin{array}{l}\text { Dependent Variable: Winter } \\
\text { wheat } \\
\text { Independent Variable: Carbon } \\
\text { dioxide emission }\left(\mathrm{CO}_{2}\right) \\
\text { temperatures, Rainfall, } \\
\text { Evapotranspiration }\end{array}$ & $\begin{array}{l}\text { The CLIMCROP (crop simulation model) simulation } \\
\text { model was used in the study, assuming that water does } \\
\text { not limit growth. High temperatures reduce crop } \\
\text { duration of certain species. For wheat, a temperature } \\
\text { increase of } 1^{\circ} \mathrm{C} \text { during grain filling is estimated to reduce } \\
\text { the length of this phase by } 5 \% \text {. }\end{array}$ \\
\hline $\begin{array}{l}\text { Alexandrov and } \\
\text { Hoogenboom } \\
(2000)\end{array}$ & $\begin{array}{l}\text { Bulgaria } \\
1961-1990\end{array}$ & $\begin{array}{l}\text { Dependent Variable: Maize yield } \\
\text { and winter wheat grain yield } \\
\text { Independent Variable: Rainfall, } \\
\text { Temperature and solar radiation }\end{array}$ & $\begin{array}{l}\text { At the current } \mathrm{CO}_{2} \text { level, the transitory } \mathrm{GCM} \text { scenarios } \\
\text { predicted a decrease in maize and winter wheat yields, } \\
\text { especially in the } 2020 \mathrm{~s}, 2050 \text { s and } 2080 \text { s. }\end{array}$ \\
\hline $\begin{array}{l}\text { Lal, M. et al. } \\
\text { (1999) }\end{array}$ & $\begin{array}{l}\text { Madhya Pradesh, } \\
\text { India } \\
\text { - Raipur }(1971 \pm 97) \\
\text { - Gwalior }(1965 \pm 88) \\
\text { - Indore }(1985 \pm 95) \\
\text { - Jabalpur }(1969 \pm 97)\end{array}$ & $\begin{array}{l}\text { Dependent Variable: Soybean } \\
\text { Independent Variable: } \mathrm{CO}_{2}\end{array}$ & $\begin{array}{l}\text { Based on simulations carried out the doubled } \mathrm{CO}_{2} \text { level, } \\
\text { the effects of future climate change on soybean yields in } \\
\text { Central India were examined using the CROPGRO model. } \\
\text { Results suggest higher yields ( } 50 \% \text { increase) for soybean } \\
\text { crop for a doubling of } \mathrm{CO}_{2} \text {. }\end{array}$ \\
\hline $\begin{array}{l}\text { Kaiser et. al. } \\
\text { (1993) }\end{array}$ & $\begin{array}{l}\text { Southern } \\
\text { Minnesota } \\
1980-2070\end{array}$ & $\begin{array}{l}\text { Dependent Variable: Crop yields, } \\
\text { crop mix, and farm revenue } \\
\text { Independent Variable: } \\
\text { Temperature }\end{array}$ & $\begin{array}{l}\text { A farm-level analysis was conducted to examine the } \\
\text { effects of climate change on farm operations and } \\
\text { profitability using the Monte Carlo simulation. Climate } \\
\text { warming scenarios used. The results indicate that grain } \\
\text { farmers in the southern region of Minnesota can } \\
\text { effectively adapt to the gradually. }\end{array}$ \\
\hline
\end{tabular}

\subsection{Ricardian (Hedonic) Approach}

It is an empirical approach based on cross-sectional data used to examine the sensitivity of agricultural production to climate change.This approach is referred to as the "Ricardian Approach" in Ricardo (1817), under the conditions of perfect competition, because of the work that promotes the net efficiency of the agricultural land of the land rent.This method is described by Mendelsohn et al. in 1994 (Gbetibouo and Hassan, 2005; Deressa et al., 2005).This approach, also called the hedonic approach, assesses the performance of the farms in climate regions.Land value or rent is considered a function of climate, demographic, economic and physical conditions (Gumel et. al., 2016). In principle, using economic data on the value of the land, it is a technique that can correct the bias in the approach of the production function (Salvo et al.,2013; 
Chen et.al., 2013). The Ricardian approach is a remarkable tool for assessing the overall impact of climate change on a specific geographical area.It has been applied to many different geographical areas in both developed and developing countries (Salvo et al.,2013).Instead of examining the yield of certain crops, this approach examines how climate in different regions affects the net rent or value of agricultural land.By directly measuring farm prices or incomes, the direct effects of climate on the yields of different crops are explained.The Ricardian approach allows measuring the economic value of different activities if markets work properly.Hence, the economic effects implied by the production function approach ensures that it can be verified as to whether or not they are reoccurring (Mendelsohn et.al., 1994).Although not explicitly mentioned, both short and long-term adaptations are included in Ricardian models.In other words, farmer adaptations are taken into consideration in order to mitigate the adverse economic effects of climate change (Olesen and Bindi, 2002). This approach is a cross-sectional method that measures the long-term effect of climate on agriculture by regressing over a series of variables such as land value or net income per hectare. This approach has three advantages: "It is relatively easy to guess, gives precise values geographically, catches adaptation" (Salvo et al., 2013). The Ricardian model measures the impact of climate factors through their contribution to the prices of agricultural land. Nevertheless, a Ricardian type model does not take into account time-independent, location-specific factors such as unobserved farming skills and soil quality (Barnwal and Kotani, 2013). In addition, the Ricardian approach does not account for the effect of unchanging variables on the region (such as carbon dioxide concentration, the effects of annual changes in the weather, changes in climate change or extreme events, and future climates) (Salvo et al., 2013). Table 2 presents the literature summary of the Ricardian Approach.

Table 2: Studies on The Impact of Climate Change on Agriculture: Ricardian (Hedonic) Approach

\begin{tabular}{|c|c|c|c|}
\hline Author & Country/Period & Variables & Results \\
\hline $\begin{array}{l}\text { Mishra and Sahu } \\
(2014)\end{array}$ & $\begin{array}{l}\text { Odisha (for all the nine } \\
\text { coastal districts) } \\
1979-2009\end{array}$ & $\begin{array}{l}\text { Dependent Variable: Farm level net- } \\
\text { revenue. } \\
\text { Independent Variable: Rainfall, } \\
\text { Temperature }\end{array}$ & $\begin{array}{l}\text { The study concluded that the July rainfall was useful } \\
\text { for the farm activity in Odisha. The study also } \\
\text { concluded that the increase in temperature for all } \\
\text { seasons had adverse effects on the agricultural } \\
\text { sector of coastal Odisha. }\end{array}$ \\
\hline Salvo et al (2013) & $\begin{array}{l}\text { Italian Alpin Region } \\
\text { 2003-2007 }\end{array}$ & $\begin{array}{l}\text { Dependent Variable: Average net } \\
\text { revenue } \\
\text { Independent Variable: Average } \\
\text { temperature, average monthly rainfall }\end{array}$ & $\begin{array}{l}\text { In contrast to the general beneficial effects of } \\
\text { climate change in the vast areas of Europe } \\
\text { (Germany and the UK), climate change has led to a } \\
\text { decline in average annual net income in the Alpine } \\
\text { region. }\end{array}$ \\
\hline $\begin{array}{l}\text { Deressa and } \\
\text { Hassan (2009) }\end{array}$ & $\begin{array}{l}\text { Ethiopia } \\
2050 \text { and } 2100\end{array}$ & $\begin{array}{l}\text { Dependent Variable: Net crop revenue } \\
\text { Independent Variable: Rainfall and } \\
\text { temperature, household, and soil } \\
\text { variables }\end{array}$ & $\begin{array}{l}\text { Special Report on Emission Scenarios (SRES) the } \\
\text { climate variable such as temperature and } \\
\text { precipitation affected slightly net crop income. In } \\
\text { addition, it has also been observed that small } \\
\text { changes in temperature during the summer and } \\
\text { winter period negatively affect net crop revenue. }\end{array}$ \\
\hline $\begin{array}{l}\text { Kabubo-Mariara } \\
\text { and Karanja (2006) }\end{array}$ & $\begin{array}{l}\text { Kenya } \\
1988-2003\end{array}$ & $\begin{array}{l}\text { Dependent Variable: Net crop revenue } \\
\text { Independent Variable: Rainfall and } \\
\text { temperature }\end{array}$ & $\begin{array}{l}\text { Global warming has an important influence on net } \\
\text { crop revenue in Kenya. However, the result is that } \\
\text { temperature is much more important than rainfall. }\end{array}$ \\
\hline $\begin{array}{l}\text { Deressa et al } \\
(2005)\end{array}$ & $\begin{array}{l}\text { South Africa } \\
\text { (11 regions) } \\
1977-1998\end{array}$ & $\begin{array}{l}\text { Dependent Variable: Sugar cane } \\
\text { production } \\
\text { Independent Variable: Rainfall, } \\
\text { temperature height and latitude }\end{array}$ & $\begin{array}{l}\text { The study concluded that sugar cane production is } \\
\text { highly sensitive to climate change. }\end{array}$ \\
\hline $\begin{array}{l}\text { Gbetibouo and } \\
\text { Hassan (2005) }\end{array}$ & $\begin{array}{l}\text { South Africa } \\
\text { (300 districts) } \\
1970-2000\end{array}$ & $\begin{array}{l}\text { Dependent Variable:Net revenue per } \\
\text { hectare } \\
\text { Independent Variable: Rainfall, } \\
\text { temperature, soil types, labour, } \\
\text { population, irrigated land and } \\
\text { geographical coordinates }\end{array}$ & $\begin{array}{l}\text { The results show that the production of field crops } \\
\text { is sensitive to marginal changes in temperature } \\
\text { compared to variations in rainfall. The increase in } \\
\text { temperature affects the net income positively, while } \\
\text { the effect of the decrease in rainfall is negative. }\end{array}$ \\
\hline $\begin{array}{l}\text { Mendelsohn and } \\
\text { Dinar (2003) }\end{array}$ & $\begin{array}{l}\text { USA } \\
1997\end{array}$ & $\begin{array}{l}\text { Dependent Variable: Farmland value } \\
\text { Independent Variable: Rainfall and } \\
\text { temperature }\end{array}$ & $\begin{array}{l}\text { The paper shows that the value of irrigated cropland } \\
\text { is not sensitive to precipitation and increases in } \\
\text { value with temperature. }\end{array}$ \\
\hline Chang (2002) & $\begin{array}{l}\text { Taiwan } \\
\text { 1977-1996 }\end{array}$ & $\begin{array}{l}\text { Dependent Variable: } 60 \text { crops } \\
\text { Independent Variable: Rainfall and } \\
\text { temperature }\end{array}$ & $\begin{array}{l}\text { The study was concluded that climate change has a } \\
\text { significant effect on crop yield. }\end{array}$ \\
\hline
\end{tabular}




\subsection{Advanced Ricardian (Panel Data) Approach}

In recent studies, a panel data approach is used to estimate the impact of rainfall and temperature change on agricultural production. This approach takes into account the fluctuations that occur randomly year-to-year in the weather conditions (Deschenes and Greenstone, 2007). The panel data approach assesses the impact of climate change on average yield and yield variability. There are two types of panel data approach found in the literature. These are fixed effect method and random effect method (Gumel et. al., 2016; Guiteras, 2007). The panel data approach, which considers fixed effects, has the advantage of controlling factors that are time invariant and unobservable (such as farmer quality or unobservable soil quality) at the regional level. Moreover, contrary to the approach of production function, the data about the real field results are used rather than the results in the laboratory environment. This means that the estimates obtained from the panel data will reflect the farmers' regulations within the year (such as changes in inputs or sowing techniques) (Guiteras, 2007). The random effect model assumes that there is no correlation between unobserved and timely independent variables and independent variables. If this assumption is neglected, the fixed effect model will provide a more unbiased assessment. For this reason, the fixed effect model gives a better estimate (Gumel et. al., 2016). Table 3 presents the literature summary of the Panel Data Approach.

\section{Table 3: Studies on The Impact of Climate Change on Agriculture: Panel Data Approach}

\begin{tabular}{|c|c|c|c|}
\hline Author & Country/Period & Variables & Results \\
\hline $\begin{array}{l}\text { Loum and } \\
\text { Fogarassy } \\
\text { (2015) }\end{array}$ & $\begin{array}{l}\text { Gambia } \\
1960-2013\end{array}$ & $\begin{array}{l}\text { Dependent Variable: Cereals } \\
\text { production (Maize and Millet) } \\
\text { Independent Variable: Rainfall, } \\
\text { temperature, } \mathrm{CO}_{2} \text {, fertilizer and } \\
\text { area planted }\end{array}$ & $\begin{array}{l}\text { A marginal increase or decrease in both rainfall and } \\
\text { temperatures may negatively affect cereals productivity. Carbon } \\
\text { dioxide has positive effects on crop yield. }\end{array}$ \\
\hline $\begin{array}{l}\text { Sarker et al } \\
(2014)\end{array}$ & $\begin{array}{l}\text { Bangladesh } \\
\text { 1972-2009 }\end{array}$ & $\begin{array}{l}\text { Dependent Variable: Various } \\
\text { types of rice (Aus, Aman ve Boro) } \\
\text { Independent Variable: Rainfall, } \\
\text { average maximum and minimum } \\
\text { temperature. }\end{array}$ & $\begin{array}{l}\text { Average maximum temperature: Aus and Aman rice are a risk- } \\
\text { augmenting factor and Boro rice is a risk-reducing factor. } \\
\text { Average minimum temperature: Boro rice is a risk-augmenting } \\
\text { factor and Aus and Aman rice are a risk-reducing factor. Rainfall: } \\
\text { Aman rice is a risk-augmenting factor and Boro and Aus rice are } \\
\text { a risk-reducing factor. }\end{array}$ \\
\hline $\begin{array}{l}\text { Dasgupta } \\
\text { (2013) }\end{array}$ & $\begin{array}{l}66 \text { countries } \\
1971-2002\end{array}$ & $\begin{array}{l}\text { Dependent Variable: Maize and } \\
\text { rice yields } \\
\text { Independent Variable: Rainfall, } \\
\text { temperature. }\end{array}$ & $\begin{array}{l}\text { Climate change affects the amount of maize and rice production } \\
\text { negatively. The increase in the variability of the climate variables } \\
\text { has a greater negative effect on the countries with lower } \\
\text { productivity for rice. }\end{array}$ \\
\hline $\begin{array}{l}\text { Barnwal and } \\
\text { Kotani (2013) }\end{array}$ & $\begin{array}{l}\text { India } \\
1971-2004\end{array}$ & $\begin{array}{l}\text { Dependent Variable: Kharif and } \\
\text { Rabi rice yields } \\
\text { Independent Variable: Rainfall, } \\
\text { temperature. }\end{array}$ & $\begin{array}{l}\text { The monsoonic crop (Kharif) is more sensitive to temperature } \\
\text { and precipitation, while the winter crop (Rabi) is quite resistant } \\
\text { to changes in climate variability. }\end{array}$ \\
\hline $\begin{array}{l}\text { Dell et al. } \\
(2012)\end{array}$ & $\begin{array}{l}125 \text { Countries } \\
1950-2003\end{array}$ & $\begin{array}{l}\text { Dependent Variable: GDP } \\
\text { Independent Variable: Average } \\
\text { temperature and rainfall }\end{array}$ & $\begin{array}{l}\text { The increase in temperature is greatly reducing the economic } \\
\text { growth in poor countries and reducing growth rates. The } \\
\text { increase in temperature leads to a decrease in agricultural } \\
\text { production, industrial production and political stability. }\end{array}$ \\
\hline Akram (2012) & $\begin{array}{l}8 \text { Asian } \\
\text { Countries } \\
1972-2009\end{array}$ & $\begin{array}{l}\text { Dependent Variable: GDP, } \\
\text { Growth rate, added value of } \\
\text { agriculture, industry and service } \\
\text { sectors. Independent Variable: } \\
\text { Rainfall, temperature, population } \\
\text { and urbanization }\end{array}$ & $\begin{array}{l}\text { The effect of temperature and rainfall increase on GDP is } \\
\text { negative. These effects are higher in the agricultural sector } \\
\text { compared to the manufacturing and service sectors. }\end{array}$ \\
\hline $\begin{array}{l}\text { Lobell et al. } \\
(2011)\end{array}$ & $\begin{array}{l}\text { USA } \\
1980-2008\end{array}$ & $\begin{array}{l}\text { Dependent Variable: Four crops } \\
\text { (maize,wheat,rice, and soybeans) } \\
\text { Independent Variable: Rainfall } \\
\text { and temperature }\end{array}$ & $\begin{array}{l}\text { Climate change shows that maize and wheat production } \\
\text { decreased by } 3.8 \% \text { and } 5.5 \% \text {, respectively. }\end{array}$ \\
\hline $\begin{array}{l}\text { Brown et al. } \\
(2010)\end{array}$ & $\begin{array}{l}133 \text { Countries } \\
1961-2003\end{array}$ & $\begin{array}{l}\text { Dependent Variable: GDP growth, } \\
\text { added value of agricultural and } \\
\text { industrial GDP, poverty } \\
\text { headcount ratio } \\
\text { Independent Variable: Rainfall } \\
\text { and temperature }\end{array}$ & $\begin{array}{l}\text { The increase in the amount of rainfall affects the share of the } \\
\text { agricultural sector in GDP positively, while the increase in } \\
\text { temperature affects the negative direction. }\end{array}$ \\
\hline $\begin{array}{l}\text { Guiteras } \\
\text { (2007) }\end{array}$ & $\begin{array}{l}\text { India } \\
1961-1999 \\
\text { (200 districts) }\end{array}$ & $\begin{array}{l}\text { Dependent Variable: Agricultural } \\
\text { outcome } \\
\text { Independent Variable: Rainfall, } \\
\text { temperature, urbanization, soil } \\
\text { quality. }\end{array}$ & $\begin{array}{l}\text { During the } 2010-2039 \text { period, crop yields are reduced by } 4.5-9 \% \\
\text { due to climate change. In the absence of long-term adaptation in } \\
\text { the } 2070-2099 \text {, the yield is predicted to decrease by } 25 \% \text { or } \\
\text { more. }\end{array}$ \\
\hline
\end{tabular}




\subsection{Time Series Approach}

To examine the relationship between climate variables and the yield of agricultural products, this approach suggests the use of past time series data on yield and climate variability. The time series approach has been extensively used to assess the impact of climate variables on the yield of various crops at global, country or regional level (Maharjan and Joshi, 2012).

Such an analysis assumes that changes in management are either unrelated to climate or originate from climate. In other words, product yields respond in the same way to rapid and gradual climate changes. These models provide a quantitative assessment of uncertainties. In order to minimize or possibly reverse the adverse effects of climate change, farmers change the cropping system as the climate changes. In addition, adaptation is expected to be a few years behind the climate trends. Because it is difficult to distinguish climate trends from natural variability and the disaggregated nature of farmer decisions (when farmers make decisions about adaptation, they are independent of each other) (Maharjan and Joshi, 2012).

Therefore, the observed data can be used when time series analysis is performed. However, in this regression analysis all possible variables affecting yields such as irrigation coverage, input use, labor utilization should be found. Therefore, in such cases, the estimation using the time series analysis is more suitable (Maharjan and Joshi, 2012). Table 4 presents the literature summary of the Time Series Approach.

Table 4: Studies on The Impact of Climate Change on Agriculture: Time Series Approach

\begin{tabular}{|c|c|c|c|}
\hline Author & Country/Period & Variables & Results \\
\hline $\begin{array}{l}\text { Rahim and } \\
\text { Puay (2017) }\end{array}$ & $\begin{array}{l}\text { Malaysia } \\
1983-2013\end{array}$ & $\begin{array}{l}\text { Dependent Variable: GDP } \\
\text { Independent Variable: } \\
\text { Farmland, temperature, } \\
\text { rainfall }\end{array}$ & $\begin{array}{l}\text { It has been concluded that there is a long run cointegration } \\
\text { relationship between variables in the study. There is a one-way } \\
\text { causality relation from rainfall, temperature and agricultural land to } \\
\text { GDP. }\end{array}$ \\
\hline $\begin{array}{l}\text { Bayraç and } \\
\text { Doğan } \\
\text { (2016) }\end{array}$ & $\begin{array}{l}\text { Turkey } \\
1980-2013\end{array}$ & $\begin{array}{l}\text { Dependent Variable: } \\
\text { Agricultural GDP } \\
\text { Independent Variable: } \mathrm{CO}_{2} \\
\text { emissions, agricultural } \\
\text { yield, temperature, rainfall }\end{array}$ & $\begin{array}{l}\text { In the study, changes in agricultural yield and rainfall have positive } \\
\text { effects on agricultural GDP, and negative effects on } \mathrm{CO} 2 \text { emissions and } \\
\text { temperature changes. Moreover, the negative effect of temperature } \\
\text { changes on the agricultural sector is more than the positive effect of } \\
\text { changes in rainfall amount. For this reason the overall impact of } \\
\text { climate change on the agricultural sector is negative. }\end{array}$ \\
\hline $\begin{array}{l}\text { Zaied and } \\
\text { Zouabi } \\
(2015)\end{array}$ & $\begin{array}{l}\text { Tunisia } \\
\text { 1980-2012 }\end{array}$ & $\begin{array}{l}\text { Dependent Variable: Olive } \\
\text { in tons } \\
\text { Independent Variable: } \\
\text { Rainfall, temperature, } \\
\text { labor and capital stock }\end{array}$ & $\begin{array}{l}\text { In long-term semi-arid areas, the olive output decreases with } \\
\text { increasing temperature. }\end{array}$ \\
\hline $\begin{array}{l}\text { Amponsah } \\
\text { et.al (2015) }\end{array}$ & $\begin{array}{l}\text { Ghana } \\
1961-2010\end{array}$ & $\begin{array}{l}\text { Dependent Variable: Cereal } \\
\text { yield } \\
\text { Independent Variable: } \mathrm{CO}_{2} \\
\text { real GDP }\end{array}$ & $\begin{array}{l}\text { The results indicate that there is significant negative link between } \mathrm{CO}_{2} \\
\text { and cereal yield. There significant positive long run and short run link } \\
\text { between cereal yield and income }\end{array}$ \\
\hline Alam (2013) & $\begin{array}{l}\text { India } \\
1971-2011\end{array}$ & $\begin{array}{l}\text { Dependent Variable: Cereal } \\
\text { yield } \\
\text { Independent Variable: } \mathrm{CO}_{2} \text {, } \\
\text { economic growth }\end{array}$ & $\begin{array}{l}\text { There is a positive and significant relationship between cereal yield and } \\
\text { economic growth, while there is a negative and significant relationship } \\
\text { between } \mathrm{CO}_{2} \text { emissions and economic growth. }\end{array}$ \\
\hline $\begin{array}{l}\text { Başoğlu and } \\
\text { Telatar } \\
\text { (2013) }\end{array}$ & $\begin{array}{l}\text { Turkey } \\
1973-2011\end{array}$ & $\begin{array}{l}\text { Dependent Variable: } \\
\text { Agricultural GDP } \\
\text { Independent Variable: } \\
\text { Rainfall, Temperature, } \\
\text { population, number of } \\
\text { diploma from secondary } \\
\text { education. }\end{array}$ & $\begin{array}{l}\text { The results indicate that precipitation has a positive impact on } \\
\text { agricultural GDP, while temperature has a negative impact. }\end{array}$ \\
\hline
\end{tabular}

\section{DATA AND METHODOLOGY}

Following the recent literature on economic impacts of climate change on agriculture, we take Aagricultural GDP as dependent variable and temperature and rainfall as the main independent variables. Data is transformed in logarithmic form as it provides consistent, better and efficient results. Annual time series data is utilized for the period of 1961-2013. All time series are taken from the World Bank, World Development Indicator database. The empirical model is given below.

Aggricultural GDP $=f$ (rainfall and temperature) 
The functional form of the model will be as:

$$
A G D P=\beta_{0}+\beta_{1} \operatorname{Rain}_{t}+\beta_{2} \text { Temp }_{t}+\varepsilon_{t}
$$

Where AGDP is the agricultural GDP as measured Agriculture, value added (\% of GDP), Rain is rainfall as measured mm and Temp is the temperature as measured ${ }^{\circ} \mathrm{C} . \mathrm{t}$ is the time trend and $\varepsilon_{t}$ is white noise error term. The parameters $B_{1}$ and $B_{2}$ and are the long-run elasticities of Agricultural GDP with respect to rainful and temperature, respectively.

We have employed the Autoregressive Distributed Lag (ARDL) bounds testing approach developed by Pesaran and Shin (1999) and Pesaran, Shin and Smith (2001) to ascertain the long-run relationship between Aggicultural GDP, Rainfall and Temperature. The ARDL approach has several advantages. First, The ARDL approach is that it can be used even in cases when different variables have different orders of integration. Second, when compared to the Johansen and Juselius cointegration test, the ARDL test ensures more consistent estimates in the case of small samples. Third, given that it is free of residual correlation, the ARDL testcan handle the eventual phenomenon of endogeneity among variables (Marques et al., 2016). Fourth, short-run adjustments can be integrated with the long-run equilibrium in ARDL by deriving the error correction mechanism (ECM) via simple linear transformation without trailing the information about long-run (Ali et al., 2017).

The mathematical representation of the ARDL approach is as follows

$$
\begin{aligned}
\Delta A G D P= & \beta_{0}+\beta_{1} \sum_{i=1}^{n} \Delta A G D P_{t-1}+\beta_{2} \sum_{i=0}^{n} \Delta \text { Temp }_{t-i}+\beta_{3} \sum_{i=0}^{n} \Delta \text { Rain }_{t-i} \\
& +\beta_{4} A G D P_{t-1}+\beta_{5} \text { Temp }_{t-1}+\beta_{6} \text { Rain }_{t-1}+\varepsilon_{t}
\end{aligned}
$$

Where $\Delta$ represents change. $\mathrm{n}$ is the optimum delay lengths. The existence of cointegration relationship between variables from Eq. 3 is examined by testing the significance of the lagged levels of variables using the F-statistic or Waldcoefficient test. Pesaran et al. (2001) propose testing $H_{0}: \beta_{4}=\beta_{5}=\beta_{6}=0$ which means that we cannot reject the absence of cointegration, against the alternative $H_{1}: \beta_{4} \neq \beta_{5} \neq \beta_{6} \neq 0$, which implies that the hypothesis of the existence of such a relationship cannot be rejected.

ARDL approach is based on two steps. First step, one is to determine the existence of a long run cointegrating relationship among the variables by using the Wald-coefficient test or F-statistics and by comparing them with critical values set out by Pesaran et al. (2001). Pesaran et al. (2001) reported two types of critical values: lower bounds and upper bounds. The critical values for the $\mathrm{I}(0)$ variables are referred to as lower-bound critical values while the critical values for the I (1) variables are referred to as upper-bound critical values. If the calculated F-Statistic is higher than the upper bounds, it means the null of hypothesis of no co-integration is rejected, indicating evidence of a long-run cointegratin relationship between the variables, regardless of the order of integration of the variables. If calculated F-statistic is below the lower bound, we cannot reject the null hypothesis of cointegration, indicating the absence of a long-run equilibrium relationship. If calculated F-statistic is between lower and upper bounds, a conclusive inference could not be made without knowing the order of integration of the underlying regressors. The second step is estimation of long-run and short-run coefficient. According to the estimation results of ARDL calculate long term coefficients. In order to investigate the short-run relationship between the variables, the error correction model based on the ARDL approach is established as follows.

$$
\Delta A G D P=\gamma_{0}+\gamma_{1} \sum_{i=1}^{n 1} \Delta A G D P_{t-1}+\gamma_{2} \sum_{i=0}^{n 2} \Delta \operatorname{Temp}_{t-i}+\gamma_{3} \sum_{i=0}^{n 3} \Delta \operatorname{Rain}_{t-i}+\gamma_{4} E C M_{t-1}+\varepsilon_{t}
$$

Where ECM(-1) term is a lagged value of the residual of model in which the long-term relationship is obtained. ECM(-1) is the speed of adjustment parameter which is expected to be negative. 


\section{FINDINGS AND DISCUSSION}

Before testing whether the Agricultural GDP, rainfall and temperature are cointegrated, we investigated the order of integration of each series. Two different unit root tests were used to assess the integration order of the series: (i) the Augmented Dickey-Fuller (ADF) test; (ii) the Phillips Perron (PP) test.

Table 5: Unit Root Tests Results

\begin{tabular}{|c|c|c|c|c|c|}
\hline & \multicolumn{2}{|c|}{ ADF Unit Root Test } & \multicolumn{2}{c|}{ Phillips-PerronUnit Root Test } & \multirow{2}{*}{ Order of integration } \\
\cline { 1 - 5 } Variables & Level & First Difference & Level & First Difference & \\
\hline AGDP & -3.185633 & -6.785477 & -3.377705 & -7.491863 & \\
& $(-3.498692)$ & $(-3.500495)$ & $(-3.498692)$ & $(-3.500495)$ & $\mathrm{I}(1)$ \\
\hline Rain & -6.574099 & - & -6.539586 & - & $\mathrm{I}(0)$ \\
& $(-3.498692)$ & & $(-3.498692)$ & & \\
\hline Temp & -6.270889 & - & -6.249822 & - & $\mathrm{I}(0)$ \\
& $(-3.498692)$ & & $(-3.498692)$ & & \\
\hline
\end{tabular}

Note: Intercept and trend model with $5 \%$ significance level.

The study applied the unit root test on the natural logarithms of the variables in level and first difference forms as shown in Table 5, Order of integration is a mixture of I (0) and I (1). In other words, the results indicate that rainfall and temperature are stationary at level while aggricultural GDP is stationary at first difference. In Table 6 contains ARDL cointegration test results. Critical values for F-Statistic are presented in Pesaran et al. (2001). Also for small samples size, that are useful for 30 to 80 observations, these critical values were recalculated in Narayan (2005).

Table 6: ARDL $(3,4,1)$ Cointegration Test Results

\begin{tabular}{|c|c|c|}
\hline Test statistic & Value & $\mathrm{k}$ \\
\hline F Statistics & 7.585593 & 2 \\
\hline \multicolumn{2}{|c|}{ Critical Value Bounds (Peseran et al 2001) } \\
\hline Significance & I0 Bound & I1 Bound \\
\hline $10 \%$ & 3.38 & 4.02 \\
\hline $5 \%$ & 3.88 & 4.61 \\
\hline $1 \%$ & 4.99 & 5.85 \\
\hline \multicolumn{2}{|c|}{ Critical Value Bounds (Narayan 2005) } \\
\hline Significance & I0 Bound & I1 Bound \\
\hline $10 \%$ & 3.573 & 4.288 \\
\hline $5 \%$ & 4.225 & 5.030 \\
\hline $1 \%$ & 5.805 & 6.790 \\
\hline
\end{tabular}

Note: $k$ shows the number of explanatory variables. Critical values for the bound test were taken from Case IV in Pesaran et al. (2001) and Narayan(2005) (Pesaran et al. 2001; Narayan, 2005).

As seen in Table 6, the calculated $\mathrm{F}$ statistic values are above the critical values. This implies that there is a long-run relationship between the mentioned variables in the period covered. Long term coefficients calculated according to the estimation results of ARDL $(3,4,1)$ model are shown in Table 7 . The results of long run estimates are presented in Table 7. The results show that the temperature has a positive and significant impact on the agricultural GDP, in the long run. The coefficient of temperature implies that an increase of $1 \%$ in temperature, it will be cause of $1.472 \%$ in aggricultural GDP in the long run in Turkey. However, the results show that the rainfall has a negative and significant impact on the agricultural GDP, in the long run. The coefficient of rainfall implies that an increase of $1 \%$ in rainfall leads to a decrease of $1.032 \%$ on agricultural GDP, in the long run in Turkey. 
Table 7: Long-Run ARDL Estimates

\begin{tabular}{|l|l|l|}
\hline \multicolumn{2}{|l|}{ Dependent variable is the natural log of Aggricultural GDP } \\
\hline Regressor & Coefficient & T-statistics (Probability) \\
\hline InTemp & 1.472744 & $2.621136(0.0126)^{*}$ \\
\hline InRain & -1.032954 & $-2.006958(0.0521)^{* *}$ \\
\hline Trend & -0.042544 & $-24.984897(0.0000)^{*}$ \\
\hline & & \\
\hline Diagnostic test statistics \\
\hline$R^{2}$ & 0.991970 \\
\hline Adj. ${ }^{2}$ & 0.989583 \\
\hline F-statistic & $415.5261(0.000000)$ \\
\hline Durbin-Watson & 2.028564 \\
\hline Serial Correlation & $0.8971(0.8204)$ \\
\hline Normality & $1.361629(0.506205)$ \\
\hline Heteroscedasticity & $0.0659(0.0839)$ \\
\hline Note: ${ }^{*}$ and ${ }^{*}$ indicate significance levels of $5 \%$ and $10 \%$, respectively.
\end{tabular}

The bottom part of Table 7 contains diagnostic test results of the selected ARDL $(3,4,1)$ model. The adjusted $R^{2}$ value of $99 \%$ suggests that rainfall and temperature jointly explain a significant part of the variation in agricultural GDP. The JB test for normality indicates that the residuals are distributed non-normal. Furthermore, from the results of the Breusch-Godfrey serial correlation LM test and the Breusch-Pagan-Godfrey heteroscedasticity test, we fail to reject the null-hypotheses of no serial correlation and no heteroscedasticity of the residuals. In other words, the functional form of the model is normal, there is no serial correlation and heteroscedasticity in our model. The residuals are normally distributed.

Next the results of the short run ARDL estimate and the coefficient of the error correction terms are presented in Table 8 .

Table 8: Short-run ARDL Estimate

\begin{tabular}{|l|l|l|}
\hline \multicolumn{3}{|l|}{ Dependent variable is the natural log of Aggricultural GDP } \\
\hline Variable & Coefficient & T-statistics (Probability) \\
\hline $\begin{array}{l}\text { D(LNAGGDP(- } \\
\text { 1)) }\end{array}$ & 0.170216 & $1.289254(0.2053)$ \\
\hline $\begin{array}{l}\text { D(LNAGGDP(- } \\
\text { 2)) }\end{array}$ & 0.336495 & $2.364978(0.0234)$ \\
\hline D(LNRAIN) & -0.043435 & $-0.669609(0.5073)$ \\
\hline D(LNRAIN(-1)) & 0.428389 & $4.134152(0.0002)$ \\
\hline D(LNRAIN(-2)) & 0.379731 & $4.160083(0.0002)$ \\
\hline D(LNRAIN(-3)) & 0.182407 & $2.239388(0.0312)$ \\
\hline$D($ LNTEMP) & 0.490778 & $3.290868(0.0022)$ \\
\hline$C$ & 2.467922 & $5.633993(0.0000)$ \\
\hline ECM(-1) & -0.548492 & $-5.727352(0.0000)$ \\
\hline
\end{tabular}

The important outcome of the short run dynamics is the calculation of the coefficient of ECM.The lagged error correction coefficients, $\mathrm{ECM}_{\mathrm{t}-1}$ are correct in sign, and significant in both cases verifying the established co-integrating relationships among the variables (Jalil et al., 2013). The ECM coefficient is negative and statistically significant. The coefficient of ECM $\mathrm{E}_{\mathrm{t}-1}$ shows the speed of the adjustment back to the long-run equilibrium after a short run shock. For example, the coefficient of $E C M_{t-1}$ is 0.5484 . This implies, nearly $55 \%$ of the disequilibria of the previous year's shock adjusting back to the long run equilibrium in the current year.

\section{CONCLUSION}

In recent years, the effects of climate change on important variables such as agriculture, industry, human health, energy demand and economic growth are being increasingly investigated. Climate change modifies the distribution of a set of climate variables including temperature, rainfall, humidity, wind speed, sunlight duration, and evaporation. In recent years, a number of studies have been conducted around the world on the impacts of climate change. Climate change affects various sectors such as agriculture, food production, fisheries, livestock, forestry, foreign trade, tourism, health, construction, logistics and finance-insurance. However, among these sectors, agriculture is a very sensitive sector to climate 
change. The effects of climate change can arise by influencing production factors and their productivity, prices and international trade patterns. Furthermore, the effects of climate change on the countries may be different. These effects, which differ from country to country, can also change agricultural competitiveness. As a result of climate change, both winners and losers can emerge. In this study, the literature on economic effects of climate change in agriculture is presented in consideration of four different approaches (Production function approach, Ricardian approach, Panel data approach, Time series approach). In these studies, it is observed that especially temperature and rainfall are used as the two most important indicators of climate change for agricultural production. In this study, important climate variables such as temperature and precipitation were used to evaluate the effects of climate change. The effects of climate variables on aggricultural GDP in Turkeywere estimated using the Autoregressive Distributed Lag (ARDL) approach. In this study, the increase in precipitation affects agricultural GDP positively, while the increase in temperature has a negative effect on agricultural GDP. In order to minimize the adverse effects of climate change in Turkey, which is one of the largest countries in the world in terms of agricultural land, it is important to establish policies, strategies, plans and programs to combat climate change. In addition, the production of agricultural products suitable for the increase in temperature in Turkey should be supported and the farmers should be aware of the adaptation to climate change. Further research on agricultural production in Turkey should take into account the impact of other climate indicators (such as solar radiation, light length, humidity, socio-economic and sea level).

\section{REFERENCES}

Adams, R. M., Hurd, B.H., Lenhart, S. \& Leary, N. 1998, “Effects of Global Climate Change on Agriculture: An Interpretative Review”, Climate Research, vol.11, pp.19-30.

Ali, W., Abdullah, A. \& Azam, M. 2017, "Re-visiting the Environmental Kuznets Curve Hypothesis for Malaysia: Fresh Evidence from ARDL Bounds Testing Approach", Renewable and Sustainable Energy Reviews, vol. 77, pp. 990-1000.

Akram, N. 2012, "Is Climate Change Hindering Economic Growth of Asian Economies?", Asia-Pacific Development Journal, vol.19, no.2, pp. $1-18$.

Aggarwal, P.K., Kumar, S.N. \& Pathak, H. 2010, "Impacts of Climate Change on Growth and Yield of Rice and Wheat in the Upper Ganga Basin", WWF-India Report.

Alam, Q. 2013, "Climate Change, Agricultural Productivity and Economic Growth in India: The Bounds Test Analysis", International Journal of Applied Research and Studies, vol.2, no.11, pp.1-14.

Alexandrov, V. A. \& Hoogenboom, G. 2000, "The Impact of Climate Variability and Change on Crop Yield in Bulgaria", Agriculture and Forest Meteorology, vol.104, pp.315-327.

Amponsah, L., Hoggar G.K. \& Asuamah, S.Y. 2015, "Climate Change and Agriculture: Modeling the Impact of Carbon Dioxide Emission on Cereal Yield in Ghana" Agriculture and Food Sciences Research, vol.2, no.5, pp.32-38.

Barnwal, P. \& Kotani, K. 2013, “Climatic Impacts Across Agricultural Crop Yield Distributions: An Application of Quantile Regression on Rice Crops in Andhra Pradesh, India", Ecological Economics, vol.87, pp.95-109.

Bayraç, H. N. \& Doğan, E. 2016, “Türkiye'de İklim Değişikliğinin Tarım Sektörü Üzerine Etkileri” Eskişehir Osmangazi Üniversitesi iiBF Dergisi, , vol.11, no.1, pp.23- 48 .

Başoğlu, A. \& Telatar, O.M. 2013, “iklim Değişikliğinin Etkileri: Tarım Sektörü Üzerine Ekonometrik Bir Uygulama”, Karadeniz Teknik Üniversitesi Sosyal Bilimler Dergisi, no.6, pp.7-25

Brown, C., Meeks, R., Ghile Y. \& Hunu, K. 2010, "An Empirical Analysis of the Effects of Climate Variables on National Level Economic Growth", World Bank's World Development Report 2010: Policy Research Working Paper 5357.

Chang, C.-C. 2002, "The Potential Impact of Climate Change on Taiwan's Agriculture". Agricultural Economics, vol.27, pp.51-64.

Chijoke, O.B., Haile, M. \& Waschkeit, C. 2011, "Implication of Climate Change on Crop Yield and Food Accessibility in Sub-Saharan Africa". ZentrumfürEntwicklungsforschung Center of Development Research University of Bonn, 131.http://www.zef.de/fileadmin/downloads/forum/docprog/Termpapers/2011_1_Oyiga_Haile_Waschkeit.pdf.

Chen, Y., Wu, Z., Okamoto, K., Han, X. Ma, G., Chien, H.\& Zhao, J. 2013, "The Impacts of Climate Change on Crops in China: A Ricardian Analysis" Global and Planetary Change, vol.104, pp. 61-74.

Cuervo, J. \& Gandhi, V.P. 1998. "Carbon Taxes: Their Macroeconomic Effects and Prospects for Global Adoption: A Survey of the Literature", Washington, IMF Working Paper, WP/98/73.

Dasgupta, S. 2013, "Impact of Climate Change on Crop Yields with Implications for Food Security and Poverty Alleviation", http://www.climateimpacts-2013.org/files/cwi dasgupta.pdf. 
Dell, M., Jones, B.F. \& Olken, B. 2012, "Temperature Shocks and Economic Growth: Evidence from the Last Half Century", American Economic Journal: Macroeconomics, vol.4, no.3, pp. 66-95.

Demir, P., \& Cevger Y., 2007, “Küresel Isınma ve Hayvancillk Sektörü”, Veteriner Hekimler Derneği Dergisi, vol.78, no.1, pp.13-16.

Deressa, T., and Hassan. R.M. 2009, " Economic Impact of Climate Change on Crop Production in Ethiopia: Evidence from Cross-Section Measures", Journal of African Economies, vol.18, pp.529-554.

Deressa, T., Hassan, R. \& Poonyth, D. 2005. "Measuring The Impact of Climate Change on South African Agriculture: The Case of Sugar cane Growing Regions", Agrekon, vol.44, no.4, pp.524-542.

Deschenes, O. \& Greenstone, M. 2007, "The Economic Impacts of Climate Change: Evidence from Agricultural Output and Random Fluctuations in Weather", The American Economic Review, vol.97, no.1, pp.354-385.

Gbetibouo, G.A. \& Hassan, R.M. 2005, "Measuring the Economic Impact of Climate Change on Major South African Field Crops: A Ricardian Approach", Global and Planetary Change, vol.47, no.2-4, pp.143-152.

Guiteras, R. 2007, "The Impact of Climate Change on Indian Agriculture", Job Market Paper. Department of Economics, University of Maryland, College Park, pp.1-52.

Gumel, D.Y., Abdullah, A.M.B., Yacob, M.R., Sood, A.M., Bose, M.M. \& Ghadimzadeh, A. 2016. "A Status Quo Review of Approach, Method, and Empirical Studies on Assessing the Impacts of Climate Change Variability on Agriculture", Journal of Agriculture and Environmental Sciences, vol.5, no.1, pp.187-199.

IPCC. Climate Change, 2007: Synthesis Report. Contributing of Working Groups I, II and III to the Fourth Assessment Report of the Intergovernmental Panel on Climate Change. IPCC, Geneva, Switzerland; [Core Writing Team, Pachauri, R.K. and Reisinger, A. (eds)]

Jalil, A., Mahmood, T. \& Idrees, M. 2013, "Tourism-Growth Nexus in Pakistan: Evidence from ARDL Bounds Tests", Economic Modelling, vol. 35, pp. 185-191.

Kabubo-Mariara, J. \& Karanja, F.K. 2006, "The Economic Impact of Climate Change on Kenyan Crop Agriculture: A Ricardian Approach" Third World Congress of Environmental and Resource Economics: Kyoto Japan, July 3-7.

Kaiser, H.M., Riha, S.J., Wilks, D.S, Rossiter, D.G. \& Sampath, R.K. 1993, "A Farm-level Analysis of Economic and Agronomic Impacts of Gradual Warming", American Journal of Agricultural Economics, vol.75, pp. 387-98.

Lal, M. Singh, K.K., Srinivasan, G., Rathore, L.S., Naidu, D. \& Tripathi, C.N., 1999, "Growth and Yield Responses of Soybean in Madhya Paradesh, India, to Climate Variability and Change", Agriculture and Forest Meteorology, vol. 93, no.1, pp.53-70.

Loum, A. \& Fogarassy, C. 2015. "The Effects of Climate Change on Cereals Yield of Production and Food security in Gambia", Applied Studies in Agribusiness and Commerce-APSTRACT, vol.9, no.4, pp. 83-92.

Lobell, D.B., Schlenker, W. \& Costa-Roberts, J. 2011, "Climate trends and global crop production since 1980". Science, vol.333, pp.616-620.

Mendelsohn, R. \& Dinar, A. 2003. Climate, Water, and Agriculture". Land Economics, vol.79, no.3, pp.328-341.

Mendelsohn, R., Nordhaus, W.D. \& Shaw, D. 1994, "The Impact of Global Warming on Agriculture: A Ricardian Analysis", The American Economic Review, vol.84, no.4, pp.753-771.

Maharjan, K.L. \& Prakash, J.N. 2012. Climate Change, Agriculture and Rural Livelihoods in Developing Countries with References to Nepal, Hiroshima International Center for Environmental Cooperation, Graduate School for International Development and Cooperation, Hiroshima University, pp. 1-203.

Marques, A.C., Fuinhas, J.A. \& Menegaki, A.N. 2016, "Renewable vs non-renewable electricity and the industrial production nexus: Evidence from an ARDL bounds test approach for Greece" Renewable Energy, vol.96, pp.645-655.

Mathauda S.S., Mavi H.S., Bhangoo B.S.\& Dhaliwal B.K. 2000, "Impact of Projected Climate Change on Rice Production in Punjab (India)". Tropical Ecology, vol. 41, no.1, pp.95-98.

Medellín-Azuara, J, Howitt, R.E., MacEwan, D.J. \& Lund, J.R. 2011, "Economic Impacts of Climate-related Changes to California Agriculture", Climatic Change, vol.109, Supplement 1, pp.387-405.

Mishra, D. \& Sahu, N.C. 2014, "Economic Impact of Climate Change on Agriculture Sector of Coastal Odisha", APCBEE Procedia, vol.10, pp.241-245.

Narayan, P.K. 2005, "The Saving and Investment Nexus for China: Evidence from Cointegration Tests", Applied Economics, vol.37, pp.1979 1990.

Olesen, J.E., Jensen, T. \& Petersen, J. 2000, "Sensitivity of Field-scale Winter Wheat Production in Denmark to Climate Variability and Climate Change". Climate Research, vol.15, pp.221-238. 
Pesaran, M.H. \& Shin, Y. 1999, “An autoregressive distributed lag modelling approach to cointegration analysis" S Strom (Ed.), Econometrics and Economic Theory in the 20th Century: The Ragnar Frisch Centennial Symposium, Cambridge University Press, Cambridge.

Peseran, M.H., Shin, Y. \& Smith, R.J. 2001, "Bounds Testing Approaches to the Analysis of Level Relationships", Journal of Applied Econometrics, vol.16, pp.289-326.

Rahim, S. \& Puay, T.G. 2017, "The Impact of Climate on Economic Growth in Malaysia". Journal of Advanced Research in Business and Management Studies, vol.6, no.2, pp.108-119.

Ricardo, D., 1817, On the Principle of Political Economy and Taxation. John Murray, London.

Sarker, M.D., Rashid, A., Alam, K. \& Gow, J. 2014, "Assessing the Effects of Climate Change on Rice Yields: An Econometric Investigation using Bangladeshi Panel Data". Economic Analysis and Policy, vol.44, pp.405-416.

Salvo, M.D., Raffaelli, R. \& Moser, R. 2013,"The impact of climate change on permanent crops in an Alpine region: A Ricardian analysis", Agricultural Systems, vol.118, pp.23-32.

Southworth, J., Randolph, J.C., Habeck, M.. Doering, O.C., Pfeifer, R.A., Rao, D.G. \&. Johnston J.J. 2000, “Consequences of Future Climate Change and Changing Climate Variability on Maize Yield in the Midwestern United States", Agriculture, Ecosystem and Environment, vol.82, no.3, pp.139-158.

Swart, R., Robinson J. \& Cohen, S. 2003, "Climate Change and Sustainable Development: Expanding the Options" Climate Policy, vol.3, Suppl. 1, pp.19-40.

UN, 1992, United Nations Framework Convention on Climate Change,http://unfccc.int/resource/docs/convkp/conveng.pdf (26.04.2014).

Zeb, A. 2013, "Climate Change and Economic Growth in Nordic Countries: An Application of Smooth Coefficient Semi-parametric Approach". International Journal of Social Sciences, vol.11, no.3, pp.159-171.

Zaied, Y.B. \& Zouabi, O. 2015, "Climate change impacts on agriculture: A panel cointegration approach and application to Tunisia", MPRA Paper No. 64711, https://mpra.ub.uni-muenchen.de/64711/1/MPRA_paper_64711.pdf.

Zhang, P., Zhang, J. \& Chen, M. 2017, “Economic impacts of climate change on agriculture: The importance of additional climatic variables other than temperature and precipitation", Journal of Environmental Economics and Management, vol.83, pp.8-31. 